\title{
Strawberry Black Root Rot and Berry Yield Are Not Affected by Terbacil Herbicide
}

\author{
Todd L. Mervosh ${ }^{1}$ and James A. LaMondia ${ }^{2}$ \\ The Connecticut Agricultural Experiment Station, Valley Laboratory, 153 Cook \\ Hill Road, P.O. Box 248, Windsor, CT 06095
}

Additional index words. Fragaria $\times$ ananassa, lesion nematode, Pratylenchus penetrans, Rhizoctonia fragariae, Sinbar

\begin{abstract}
The effects of terbacil herbicide on strawberry (Fragaria xananassa Duch. 'Honeoye') yield and black root rot disease were determined in field plots at two locations in Connecticut over 4 years. Terbacil treatments at up to four times the maximum label dosage caused some temporary foliar chlorosis but did not affect the health of structural or perennial roots and associated feeder roots. Development of secondary root growth (perennial roots) was not influenced by terbacil. Terbacil had no effect on the quantity of lesion nematodes [Pratylenchus penetrans (Cobb) Filip \& Schur. Stek.] extracted or the amount of the fungal pathogen Rhizoctonia fragariae Husain and McKeen isolated from strawberry roots. At both locations, $R$. fragariae was common on plant roots by the fourth year. Terbacil treatments did not affect strawberry yields in terms of number or weight of ripe berries per plot. Our results indicate that terbacil does not contribute to black root rot or decreased yields in 'Honeoye' strawberry. Chemical name used: 5-chloro-3-(1,1dimethylethyl)-6-methyl-2,4-(1H,3H)-pyrimidinedione (terbacil).
\end{abstract}

The herbicide terbacil (Sinbar80WP; E. I. du Pont de Nemours \& Co., Wilmington, Del.) is often used in strawberry (Fragaria $\times$ ananassa) production for early postemergence and residual preemergence weed control. Other than 2,4-D, terbacil is the only herbicide registered for use in strawberries that controls a wide range of broadleaf weeds (Bonanno, 2003). However, in response to grower complaints that terbacil injured strawberries in some situations, DuPont removed strawberries from the Sinbar product label in 1991, and issued a supplemental Sinbar label for strawberries (DuPont Agricultural Products, 1991). This supplemental label, in effect when field research for this paper was conducted, set a maximum annual application rate of $0.56 \mathrm{~kg} \cdot \mathrm{ha}^{-1}$ of product $\left(0.45 \mathrm{~kg} \cdot \mathrm{ha}^{-1}\right.$ of terbacil) for strawberries. Terbacil could not be applied to soils containing $<2 \%$ organic matter and could not be applied until plants had been established in the field for at least 6 months. In addition, terbacil could only be applied at two specific times: to dormant plants in late fall, and after postharvest renovation before new leaf growth (DuPont Agricultural Products, 1991).

Some studies have reported that terbacil reduced strawberry vigor or berry yield. However, in all of these cases injury occurred when terbacil was applied at rates of $0.56 \mathrm{~kg} \cdot \mathrm{ha}^{-1}$ a.i. or higher to newly planted strawberries or during the transplant year (Ahrens, 1982; Doohan et al., 1993; Masiunas and Weller, 1986; Weller, 1984). We found no reports of terbacil causing

Received for publication 7 July 2003. Accepted for publication 17 Feb. 2004. We thank Jane Morrison, David Laiuppa, Steven Lamoureux, Doug Gaskill, and Rob Ballinger for technical assistance with this project.

${ }^{1}$ Weed scientist. To whom reprint requests should be addressed; e-mail todd.mervosh@po.state.ct.us.

${ }^{2}$ Plant pathologist. significant injury to strawberries when applied according to the use directions on the 1991 supplemental label for Sinbar.

Strawberry black root rot is a serious disease that is characterized by blackening of roots and associated poor growth and yield (Maas, 1984). Black root rot of perennial strawberries is described as a complex root cortical disease caused by the binucleate fungus Rhizoctonia fragariae (Martin, 1988; Wilhelm et al., 1972). The lesion nematode Pratylenchus penetrans has been associated with increased severity of black root rot (Chen and Rich, 1962; Goheen and Bailey, 1955; Goheen and Smith, 1956; LaMondia, 1994; LaMondia, 2002; LaMondia and Martin, 1989; Riggs et al., 1956). The mechanism by which $P$. penetrans affects development of black root rot is unknown. However, the effect appears to be local rather than systemic because $R$. fragariae infection is higher in and near nematode lesions but not at distant areas on the root or on other roots (LaMondia, 2003).

The morphology of strawberry roots may contribute to the difficulty in understanding black root rot. Three distinct types of roots exist on crowns at the same time, and the relative abundance of each morphological type varies with time (Wilhelm and Nelson, 1970). New structural roots (perennial roots) are produced from crowns. The terminal branches of these roots are fine lateral or feeder roots. These feeder roots do not develop secondary tissues and have a limited life span, and may be replaced several times each season. The structural roots develop suberized secondary tissues and eventually become dark or black perennial roots due to the collapse of epidermal and cortical cells. These roots appear to be diseased but may be functional and healthy, despite loss of the cortex. Perennial roots act as storage organs and conduct water without mineral uptake. All these root types have specific functions and are necessary for the growth and survival of the strawberry crown. Lesion nematode symptoms are commonly seen on young structural roots. Nematode infection may reduce overall root growth, stimulate suberized root production, or change the balance between root types, influencing strawberry growth and vigor (Wilhelm and Nelson, 1970).

We havefound that $R$. fragariae is commonly resident on the sloughed cortex of healthy perennial roots (LaMondia, 2003; LaMondia and Martin, 1989). From this source, the fungus may then infect structural or feeder roots, especially when the plant is under stress or when roots are damaged. Lesion nematodes aggregate in the root cortex. Direct effects of nematode feeding and movement are cell damage and death. Indirect effects of nematode infection are discoloration of the endodermis and early polyderm formation, which results in localized areas of secondary growth and cortical cell weakening or death. Cells weakened by $P$. penetrans are more susceptible to $R$. fragariae, leading to increased infection and cortical root rot (LaMondia and Martin, 1989).

Strawberry black root rot has been associated with a number of other pathogens and environmental conditions (Wilhelm, 1984; Wing et al., 1994). Either directly or indirectly, factors such as soil texture, moisture, temperature, and soil compaction are often associated with strawberry black root rot (Maas, 1984; Wing et al., 1994).

A 1992 survey of 27 strawberry growers in New York found a correlation $\left(P<0.01, r^{2}=\right.$ 0.26 ) between terbacil application rate and a lack of healthy feeder roots (Wing et al., 1995). The use of other herbicides was not associated with strawberry root health. Other factors negatively correlated with roothealth were soil compaction, fine soil texture, absence of raised beds, non-use of fungicides, soil fumigation, advanced age of planting, and cumulative years of strawberry monoculture (Wing et al., 1995). The authors stated that no single factor represented a major part of the variation in root health ratings. Thus, they suggested several interacting factors were necessary to cause strawberry black root rot (Wing et al., 1995), a view consistent with that ofWilhelm(1984) who characterized black root rot as a disease complex.

No scientific studies have been published to investigate terbacil effects on strawberry root health and black root rot development. Our objectives were to examine the effects of repeated terbacil treatments on the prevalence of root rot symptoms and black root rot pathogens, overall strawberry vigor, and berry yield. An experiment in which all factors are kept equal except for terbacil dosage is important to determine if a causal relationship exists between use of terbacil and strawberry black root rot. Strawberry growers need to know if this herbicide poses a risk to their crop.

\section{Materials and Methods}

The experiment was conducted at research farms of The Connecticut Agricultural Experiment Station in Windsor and Hamden, Conn. Soil type in Windsor was Merrimac sandy 
Table 2. Effects of terbacil application rate on isolation of strawberry black root rot pathogens Pratylenchus penetrans and Rhizoctonia fragariae from strawberry roots in field plots in Windsor and Hamden, Conn.

\begin{tabular}{|c|c|c|c|c|c|c|c|c|c|}
\hline \multirow[b]{2}{*}{ Location } & \multirow{2}{*}{$\begin{array}{c}\text { Terbacil } \\
\left(\mathrm{kg} \cdot \mathrm{ha}^{-1} \cdot \mathrm{yr}^{-1}\right)\end{array}$} & \multicolumn{4}{|c|}{ Pratylenchus per $2 \mathrm{~g}$ root } & \multicolumn{4}{|c|}{ Percent root sections with Rhizoctonia } \\
\hline & & 1996 & 1997 & 1998 & 1999 & 1996 & 1997 & 1998 & 1999 \\
\hline \multirow[t]{4}{*}{ Windsor } & 0 & 53.3 & 25.3 & 25.0 & 72.5 & 0.0 & 4.2 & $\mathrm{ND}^{\mathrm{z}}$ & 21.7 \\
\hline & 0.45 & 130.0 & 7.7 & 20.0 & 22.5 & 16.7 & 12.5 & ND & 15.0 \\
\hline & 0.9 & 70.0 & 13.0 & 45.0 & 80.0 & 8.3 & 4.2 & ND & 16.7 \\
\hline & 1.8 & 95.0 & 9.0 & 105.0 & 110.0 & 0.0 & 4.2 & ND & 13.3 \\
\hline \multirow[t]{4}{*}{ Hamden } & 0 & 35.0 & 0.3 & 0.0 & 7.5 & 0.0 & 8.3 & ND & 35.0 \\
\hline & 0.45 & 15.0 & 1.0 & 0.0 & 5.0 & 0.0 & 8.3 & ND & 35.0 \\
\hline & 0.9 & 0.0 & 2.3 & 5.0 & 20.0 & 8.3 & 8.3 & ND & 41.7 \\
\hline & 1.8 & 23.3 & 15.3 & 0.0 & 10.0 & 0.0 & 4.2 & ND & 41.7 \\
\hline Source (ANOVA) & & \multicolumn{4}{|c|}{$P=$ Pratylenchus per $2 \mathrm{~g}$ root } & \multicolumn{4}{|c|}{$P=$ root sections with Rhizoctonia } \\
\hline Terbacil treatment & & \multicolumn{4}{|c|}{ NS } & \multicolumn{4}{|c|}{ NS } \\
\hline Location & & \multicolumn{4}{|c|}{0.001} & \multicolumn{4}{|c|}{ NS } \\
\hline Terbacil $\times$ location & & \multicolumn{4}{|c|}{ NS } & \multicolumn{4}{|c|}{ NS } \\
\hline
\end{tabular}

${ }^{\mathrm{z}} \mathrm{ND}=$ analysis not done.

${ }^{\text {NSNonsignificant. }}$

Table 3. Effects of terbacil application rate on number and weight of strawberries harvested from field plots in Windsor and Hamden, Conn.

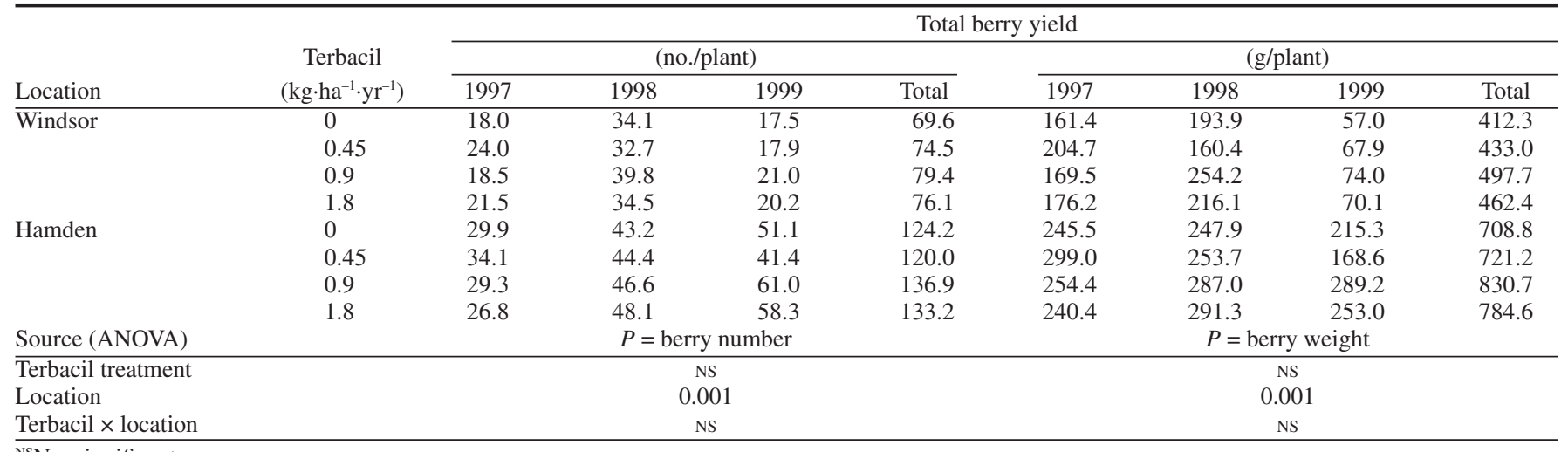

Ns Nonsignificant.

application rate and reduction in healthy feeder roots (Wing et al., 1995). As a result, the authors suggested high levels of terbacil might predispose plants to black root rot. Our experimental results do not support that hypothesis.

Terbacil is a root-absorbed photosynthesis inhibitor that is translocated to the leaves where it can cause chlorosis (Masiunas and Weller, 1986; Vencill, 2002). In our study, terbacil applied at four times the maximum labeled rate to strawberry plants in low organic matter soils caused temporary leaf chlorosis. However, terbacil treatments did not increase black root rot symptoms or reduce berry yields. 'Honeoye', the cultivar evaluated, has average susceptibility to terbacil relative to other strawberry cultivars (Masiunas and Weller, 1986). Fields at both sites were naturally infested with black root rot pathogens.

A causal relationship linking a herbicide and a disease cannot be established through a simple correlation analysis. Other explanations are possible for the association of terbacil with strawberry black root rot reported by Wing et al. (1995), who found several other physical and cultural factors were correlated with poor root health. For example, use of herbicides such as terbacil may allow growers to extend the productive life of strawberry plantings additional years, making eventual development of root diseases more likely. Additionally, weed populations often become more competitive in aging strawberry plantings, so growers are more likely to apply terbacil to older, weedy strawberry fields that are declining from black root rot than to vigorous new plantings.

In 2002 (after field research for this paper was complete), DuPont revised the supplemental label for Sinbar to allow application to soils containing at least $0.5 \%$ organic matter (DuPont Crop Protection, 2002). For coarsetextured soils (sands, sandy loams) with $0.5 \%$ to $1 \%$ organic matter, the maximum annual dosage is $0.42 \mathrm{~kg} \cdot \mathrm{ha}^{-1}$ of product $\left(0.34 \mathrm{~kg} \cdot \mathrm{ha}^{-1}\right.$ of terbacil), and no more than half this dosage can be applied at one time. For coarse-textured soils with $1 \%$ to $2 \%$ organic matter and for medium- and fine-textured soils with $0.5 \%$ to $2 \%$ organic matter, the maximum annual dosage is $0.56 \mathrm{~kg} \cdot \mathrm{ha}^{-1}$ of product, and no more than half this dosage can be applied at one time. For established strawberry plantings in soils containing $>2 \%$ organic matter, up to 0.56 $\mathrm{kg} \cdot \mathrm{ha}^{-1}$ of product can be applied at postharvest renovation and again in late fall (DuPont Crop Protection, 2002).

Because the soils used in our study contained between $1 \%$ and $2 \%$ organic matter, terbacil use is now allowed in these soils at a maximum annual dosage of $0.56 \mathrm{~kg} \cdot \mathrm{ha}^{-1}$ of product $\left(0.45 \mathrm{~kg} \cdot \mathrm{ha}^{-1}\right.$ of terbacil). Thus, the terbacil application rates in our study were equivalent to one, two and four times the labeled dosages for Sinbar use in strawberries.

Another change in the supplemental label is that Sinbar can now be applied after transplanting strawberries in a matted-row production system at rates of 0.14 to $0.21 \mathrm{~kg} \cdot \mathrm{ha}^{-1}$ of product
(DuPont Crop Protection, 2002). Application must occur before new runner plants start to root, and prior to new foliage growth.

Our results indicate that strawberry growers can utilize terbacil according to label directions without contributing to risk of black root rot or reduced berry yields. Of course, some variation exists in sensitivity of strawberry cultivars to terbacil, so growers should be careful not to exceed application rates specified for their soil type. Management of black root rot should focus on the pathogens causing the disease and on minimizing cultural practices and environmental conditions that increase disease severity.

\section{Literature Cited}

Ahrens, J.F. 1982. Napropamide and terbacil for newly planted strawberries. Adv. Strawberry Prod. 1:22-26.

Barker, K.R. 1985. Nematode extraction and bioassays, p. 19-35. In: K.R. Barker, C.C. Carter, and J.N. Sasser (eds.). An advanced treatise on Meloidogyne. vol. 2. Methodology. N.C. State Univ. Graphics, Raleigh.

Bonanno,A.R. 2003. Strawberry weed management, p. 51-56. In: S. Schloemann (ed.). New England small fruit pest management guide 2003-2004. Univ. Mass. Coop. Ext. System, Amherst.

Chen, T.A. and A.E. Rich. 1962. The role of Pratylenchus penetrans in the development of strawberry black root rot. Plant Dis. Rpt. 46:839-843.

Doohan, D.J., T.J. Monaco, and T.J. Sheets. 1993. Management of field violet (Viola arvensis) in strawberries (Fragaria xananassa). Weed 
Technol. 7:185-189.

DuPont Agricultural Products. 1991. Supplemental labeling: DuPont ${ }^{\mathrm{TM}}$ Sinbar ${ }^{\circledR}$ Herbicide for weed control in strawberries in selected northeastern states. DuPont Agricultural Products, Del.

DuPont Crop Protection. 2002. Supplemental labeling: DuPont ${ }^{\mathrm{TM}}$ Sinbar ${ }^{\circledR}$ Herbicide for weed control in strawberries (except California). DuPont Agricultural Products, Del.

Goheen, A.C. and J.S. Bailey. 1955. Meadow nematodes in strawberry plantings in Massachusetts. Plant Dis. Rpt. 39:879-880.

Goheen, A.C. and J.B. Smith. 1956. Effects of inoculation of strawberry roots with meadow nematodes, Pratylenchus penetrans. Plant Dis. Rpt. 40:146-149.

LaMondia, J.A. 1994. The association of lesion nematodes with black root rot in strawberry fields. NE-SARE Small Fruits Nwsl. 4:10-11.

LaMondia, J.A. 2002. Seasonal populations of lesion and root-knot nematodes in strawberry roots. J. Nematol. 34:409-413.

LaMondia, J.A. 2003. The interaction of Pratylenchus penetrans and Rhizoctonia fragariae in strawberry black root rot. J. Nematol 35:17-22.

LaMondia, J.A. and S.B. Martin. 1989. The influence of Pratylenchus penetrans and temperature on black root rot of strawberry by binucleate Rhizoctonia spp. Plant Dis. 73:107-110.

Maas, J.L. (ed.). 1984. Compendium of strawberry diseases. Amer. Phytopathol. Soc. Press, St. Paul, Minn.

Martin, S.B. 1988. Identification, isolation frequency, and pathogenicity of anastomosis groups of binucleate Rhizoctonia spp. from strawberry roots. Phytopathology 78:379-384.

Masiunas, J.B. and S.C. Weller. 1986. Strawberry cultivar response to postplant applications of terbacil. HortScience 21:1147-1149.

Riggs, R.D., D.A. Slack, and J.P. Fulton. 1956. Meadow nematode and its relation to decline of strawberry plants in Arkansas. Phytopathology 46:24.

Vencill, W.K. (ed.). 2002. Herbicide handbook. $8^{\text {th }}$ ed. Weed Sci. Soc. Amer., Lawrence, Kans.

Weller, S.C. 1984. Evaluation of postplant applica- tions of terbacil and napropamide to strawberry plants. Adv. Strawberry Prod. 3:15-19.

Wilhelm, S. 1984. Black root rot, p. 90. In: J.L. Maas (ed.). Compendium of strawberry diseases. Amer. Phytopathol. Soc. Press, St. Paul, Minn.

Wilhelm, S. and P.E. Nelson. 1970. A concept of rootlet health of strawberries in pathogen-free soil achieved by fumigation, p. 208-215. In:T.A. Toussoun, R.V. Bega and P.E. Nelson (eds.). Root diseases and soil-borne pathogens. Univ. Calif. Press, Berkeley.

Wilhelm, S., P.E. Nelson, H.E. Thomas, and H. Johnson. 1972. Pathology of strawberry root rot caused by Ceratobasidium species. Phytopathology 62:700-705.

Wing, K.B., M.P. Pritts, and W.F. Wilcox. 1994. Strawberry black root rot. Adv. Strawberry Res. 13:13-19.

Wing, K.B., M.P. Pritts, and W.F. Wilcox. 1995. Biotic, edaphic, and cultural factors associated with strawberry black root rot in New York. HortScience 30:86-90. 